WellBeing International

WBI Studies Repository

8-1981

\title{
Behavioural Budgeting by Wild Coyotes: The Influence of Food Resources and Social Organization
}

Marc Bekoff

University of Colorado

Michael C. Wells

University of Colorado

Follow this and additional works at: https://www.wellbeingintlstudiesrepository.org/acwp_ena

Part of the Animal Studies Commons, Behavior and Ethology Commons, and the Comparative Psychology Commons

\section{Recommended Citation}

Bekoff, M., \& Wells, M. C. (1981). Behavioural budgeting by wild coyotes: the influence of food resources and social organization. Animal Behaviour, 29(3), 794-801.

This material is brought to you for free and open access by WellBeing International. It has been accepted for inclusion by an authorized administrator of the WBI Studies Repository. For more information, please contact wbisr-info@wellbeingintl.org.

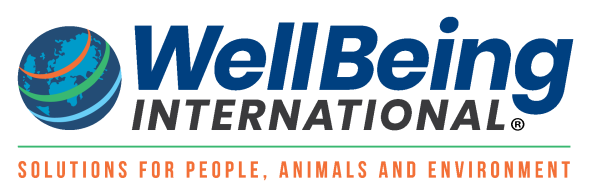




\title{
Behavioural Budgeting by Wild Coyotes: The Influence of Food Resources and Social Organization
}

\author{
Marc Bekoff and Michael C. Wells
}

University of Colorado

\begin{abstract}
$\underline{\text { ABSTRACT }}$
Daytime behavioural budgets of coyotes (Canis latrans) living in the Grand Teton National Park Jackson, Wyoming, were analysed in order to determine how activity patterns ' ere influenced by food resources and social organization. In winter coyotes rested more-and hunted less than in other seasons. Pack-living coyotes rested more and travelled less than resident pairs or solitary resident or transients during winter months when the major food resource was ungulate (predominantly elk, Cervus canadensis) carrion. A mated female living in a pack rested significantly more and travelled significantly less than a mated female living only with her mate (as a resident pair) during winter. We predict that in times of food shortage, pack-living coyotes, and particularly reproductive females might be at an advantage when compared to resident pairs and solitary individual.
\end{abstract}

The way in which wild animals budget their time on daily and annual bases is of interest to behavioural ecologists, behavioural physiologists, physiological ecologists, and wildlife biologists (Moen 1973; Turner 1979; McNab 1980). These data are particularly revealing when it can be shown that activity patterns are affected by proximate variables such as food supply, reproductive activities, and social organization, and that there is intraspecific variability even among sympatric conspecifics (Altmann 1974; Coelho et al. 1979).

Athough a good deal is known about daily activity rhythms in wild coyotes (C. latrans) from radiotelemetric studies (Ozoga \& Harger 1966; Gipson \& Scalander 1972; Bowen 1978; Andelt \& Gipson 1979; see Mottus (1969) for activity data on captive coyotes and Shield (1972) and Litvaitis \& Mautz (1980) for energetic data for captive coyotes), very little is actually known about seasonal trends in behavioural budgeting by wild coyotes that is comparable to data relating food ecology and activity patterns for wolves (C. lupus; Mech 1977) in Minnesota. One reason for the lack of information stems from the fact that freeranging coyotes are extremely difficult to observe directly in most habitats throughout the year. Consequently, detailed information about behavioural patterns, other than that indirectly inferred from radio-tracking and unsubstantiated by direct comparisons of observed behaviour with specific radio-signal patterns (e.g. Laundré 1979), is very difficult to gather. 
The purpose of this study was to analyse daytime behavioural budgets of directly observable coyotes living in the Grand Teton National Park, Jackson, Wyoming. Some of the questions with which we were concerned included: (1) What was the overall time budgeting of activity by all individuals and how did this vary seasonally? (2) Were there differences in activity patterns among coyotes living in different types of social group? (3) Did mated pairs living in different types of social groups differ in activity patterns during the mating season (which in turn could be related to food supply)? (4) Were there differences in behavioural budgeting among coyotes living in packs?

\section{Methods}

Data were collected by direct observation of individual coyotes between September 1977 and 4 April 1980 in the area of Blacktail Butte, in the southeast corner of the Grand Teton National Park, approximately $20 \mathrm{~km}$ north of the town of Jackson, Wyoming. The mean annual temperature at the village of Moose, close to the study area, is 2.41 C (U.S. Department of Commerce Weather Bureau records 1950-1975), ranging from a monthly mean of $15 \mathrm{C}$ in July to - $10 \mathrm{C}$ in January. During winter 1978-1979, temperatures dropped as low as - $40 \mathrm{C}$. Coyotes were observed for $526 \mathrm{~h}$. The average number of coyotes in view at any one time was 1.77. Therefore, the actual total number of 'coyote-hours' was 933. Coyotes were observed for 122 coyote-hours in fall (August to November), 612 in winter (December to March), and 199 in spring/summer (April to July). Animals were observed during daylight hours but were not observed after sunset. About 50 different individuals were observed using focal-animal (group) sampling; 32 coyotes bad been previously fitted with coloured ear-tags (Rototags) and/or radio-collars (AVM suppliers). Standard procedures were used for deodorizing, setting, and baiting the Victor $3 \mathrm{~N}$ traps (see Gipson \& Sealander 1972; Hawbaker 1974). From the butte, which rises about $300 \mathrm{~m}$ off the valley floor, coyotes were easily observed using Bushnell Spacemaster II spotting scopes equipped with 20-mm lenses, with low power $(7-10 \times)$ binoculars, or with the naked eye as they roamed in the open habitat consisting of various short grasses and sagebrush (Artemisia spp.; see Cole (1969) and Oswald (1966) for details about vegetation) or as they travelled on snow-covered ground. All measures of time were taken using digital stop-watches (Cronus II or Fisher). These watches were easy to read in the field and contained various programs so that more than one animal or sequence of events could be timed simultaneously. Observations were read into a Sony microcassette recorder (model 101) and later transscribed. We kept record of the frequencies of occurrence and the time spent in various activities. We waited for an animal to change its activity (after we a arrived) before we collected data. Tests for analysing the difference between two proportions were performed using the $t_{\mathrm{s}}$ statistic (see Sokal \& Rohlf (1969) pp. $607 \mathrm{ff}$.). Critical values of $t_{\mathrm{s}}$ are: 1.96, $P<0.05 ; 2.58, P<0.01$; and 3.30, $P<0.001$. When three or more proportions were involved, paired $t_{\mathrm{s}}$ comparisons were performed only after doing the $X^{2}$ analysis for testing the differences among three or more proportions as suggested by Snedecor (1956).

\section{Classes of Coyote Social Organization}

Coyote social organization was classified using Bowen's (1978) schema. Social classes included transients (single individuals showing no site attachment), solitary residents (lone individuals living in a defined home range, but not defending a territory, resident pairs (mated pairs occupying a defined borne range, but not defending a territory), and packs (groups of coyote consisting of about three to eight individuals occupying a defined home range and defending a territory). All of these classes were observed around Blacktail Butte (see Bekoff \& Wells 1980).

\section{Definition of Terms}

Seven major types of activities were considered (all were mutually exclusive except 'at carrion') and defined as follows: 
1. Rest. Coyote was lying down (not sitting) on its side or stomach; frequently it was not possible to determine whether the coyote was sleeping; occasionally the animal would turn its bead from side to side and scan its surroundings.

2. Travel. Coyote walked or trotted slowly at a steady pace, averaging about $5 \mathrm{~km} / \mathrm{h}$ and covering at least about $200 \mathrm{~m}$; travelling during hunting was not included.

3. Hunt. An active attempt to capture live small rodents such as Uinta ground squirrels (Spermophilus armatus), northern pocket gophers (Thomomys talpoides), or field voles (Microtus spp.; see Weaver (1977) for details about food habits and Vincent \& Bekoff (1978), Beko \& Wells (1980), and Wells \& Lehner (1978) for descriptions of bunting behaviours).

4. Eat. Coyote obviously chewing on something and ingesting it.

5. Play. Coyote playing either socially or with an object (see Bekoff (1974) and Bekoff \& Byers (1981) for definitions and descriptions of play).

6. Aggression. Fight or threat interactions during which one coyote was dominated (see Bekoff (1974) and Lehner (1978) for descriptions of behaviours).

7. At carrion. Coyote was within about 5 to $20 \mathrm{~m}$ of ungulate carrion, almost always from elk (Cervus canadensis); occasionally, domestic cow or pronghorn antelope (Antilocapra americana) carcasses were available, but not during winter. Large ungulates were never observed to be killed by coyotes. Murie (1951) and others concluded that elk were represented in coyote diets by carrion only (see also Bekoff 1977). Availability of ungulate carrion was due to death by natural causes (Murie 1951) or human bunting (see below). While at carrion, coyotes could engage in other activities such as resting, playing, or eating.

\section{Results}

Food Resources and Reproduction

Food resources changed seasonally. During winter months (December to March), coyotes were primarily dependent on ungulate carrion (predominantly elk) for food. About 110 piles of viscera and carcasses were located on our study area at the beginning of winter. It is important to note that elk carrion on our study area resulted almost totally from the limited human hunting season in November; hence there was a decline in carrion availability as winter progressed. By late March there were about 5 to 10 elk carcasses with meat on the study area. Rodents were available during winter but were difficult to catch because of snow cover (about $1 \mathrm{~m}$ on the average in winter). However, Uinta ground squirrels, the major food item for coyote living around the butte from April to August were not available because they hibernated. During spring/summer (April to July), coyotes were primarily dependent on small rodents, especially Uinta ground squirrels. A few $(<5)$ cow carcasses were usually available as well. During fall (August to November), coyotes fed mainly on rodents other than Uinta ground squirrels and had access to very few cow carcasses. (In coyotes, there is a high correlation between what observers see coyotes eat and the major food items found in scats and stomachs. These latter types of analyses for coyotes living in and around our study area support our observation of changing food habits (Weaver 1977).)

Coyotes began to form pair bonds in December and courted until late February, when copulation (and the copulatory tie) was observed. Pups were born in late April of each year (gestation period of about 63 days).

\section{Seasonal Behavioural Budgets}

All values referred to below have been standardized for the number of hour that coyotes were in view ('coyote-hour') during each time period. Frequency should be read as the 'relative frequency (RF, Table 1) of occurrence per coyote-hour'. 
Table 1. Relative Frequencies of Occurrence per Coyote-Hour (RF) and Mean Bout Lengths (MBL) of Seven Activities throughout the Year

\begin{tabular}{|c|c|c|c|c|c|c|c|c|}
\hline Season & & $\begin{array}{c}\text { Rest } \\
(N=631)\end{array}$ & $\begin{array}{c}\text { Travel } \\
(N=648)\end{array}$ & $\begin{array}{c}\text { Hunt } \\
(N=386)\end{array}$ & $\begin{array}{l}\text { At Carrion } \\
(N=263)\end{array}$ & $\begin{array}{c}\text { Play } \\
(N=131)\end{array}$ & $\begin{array}{c}\text { Aggression } \\
(N=161)\end{array}$ & $\begin{array}{c}\text { Eat } \\
(N=254)\end{array}$ \\
\hline Fall $(F)$ & $N$ & 64 & 105 & 122 & 10 & 19 & 28 & 59 \\
\hline \multirow[t]{2}{*}{$(122$ h) } & $\mathrm{RF}$ & 0.52 & 0.86 & 1.00 & 0.08 & 0.16 & 0.23 & 0.48 \\
\hline & MBL (Min) & 26.3 & 14.7 & 25.7 & 11.7 & 9.5 & 5.7 & 6.4 \\
\hline Winter (W) & $N$ & 451 & 376 & 112 & 223 & 92 & 101 & 124 \\
\hline \multirow[t]{2}{*}{$(612 \mathrm{~h})$} & $\mathrm{RF}$ & 0.74 & 0.61 & 0.18 & 0.36 & 0.15 & 0.17 & 0.20 \\
\hline & MBL (Min) & 52.8 & 20.3 & 24.6 & 23.9 & 5.2 & 2.8 & 10.1 \\
\hline Spring/Summer & $N$ & 116 & 167 & 152 & 30 & 20 & 32 & 71 \\
\hline (SS) & RF & 0.58 & 0.84 & 0.76 & 0.15 & 0.10 & 0.16 & 0.36 \\
\hline$(199 \mathrm{~h})$ & MBL (Min) & 26.2 & 16.7 & 34.8 & 12.8 & 10.4 & 3.3 & 1.9 \\
\hline \multirow[t]{3}{*}{ †RF tests } & & $F=S S$ & $F=S S$ & $\mathrm{~F}>\mathrm{W}, \mathrm{SS}^{\star \star \star}$ & $F=S S$ & $\mathrm{~F}=\mathrm{W}=\mathrm{SS}$ & $\mathrm{F}=\mathrm{W}=\mathrm{SS}$ & $F>W^{\star \star \star}$ \\
\hline & & $W>F, S^{\star \star *}$ & $\mathrm{~W}<\mathrm{F}, \mathrm{SS}^{\star \star \star *}$ & 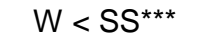 & $W>F, S^{\star \star \star *}$ & & & $\mathrm{~F}>\mathrm{SS}^{*}$ \\
\hline & & & & & & & & $W>S S^{\star \star \star}$ \\
\hline \multirow[t]{4}{*}{ ‡MBL tests } & $H$ value & 9.4 & 6.3 & 4.6 & 8.4 & 2.4 & 1.8 & 8.1 \\
\hline & & $F=S S$ & $F=S S$ & $F=W=S S$ & $W>F, S S$ & $\mathrm{~F}=\mathrm{W}=\mathrm{SS}$ & $\mathrm{F}=\mathrm{W}=\mathrm{SS}$ & $W>F, S S$ \\
\hline & & $W>F, S^{\star \star *}$ & $W>F$ & & $F=S S$ & & & \\
\hline & & & $W=S S$ & & & & & \\
\hline
\end{tabular}

†Values for different seasons were compared using proportions tests; see Methods; ${ }^{*} P>0.05,{ }^{* \star \star} P<0.01$. All comparisons indicated as equal were not significant, $P<0.05$.

$\ddagger$ Kruskal-Wallis one-way ANOVA; critical value of $H(P<0.05)=5.7$. All seasonal comparisons were based on an a posteriori nonparametric multiple comparisons STP test (Sokal \& Rohlf 1969, pp. 396 ff.).

Resting. Coyote rested most frequently (Table I) and for the greatest proportion of total time in winter $(P<0.001$; Fig. 1) when compared to other seasons. Resting bouts in winter were also on the average almost twice as long as those in fall or spring/summer (MBL; Table 1).

Travelling. Although less time was available for travelling during winter due to the large amount of time spent resting during that season, the proportion of time spent travelling was similar during the entire year $(P>0.05$; Fig. 1). However travel frequency was lowest during winter while the mean duration of each move was about the same during winter and spring/summer (Table 1).

Hunting. Coyotes hunted least frequently (Table 1), and for the least proportion of total time, during winter $(P<0.001$; Fig. 1). However, each hunt lasted about the same length of time throughout the year (Table 1). Hunting was performed for the greatest (and the same, $P>0.05$ ) relative percentage of time in fall and spring/summer (Fig. 1), though more frequently during fall (Table 1). Between March (5.4\%) and April (31.1\%) the proportion of time spent hunting increased $25.7 \%(P<0.001)$, as did hunting frequency (0.14, March; 0.71, April). During April, snow melted and rodents were more accessible and Uinta ground squirrels emerged. Coyotes spent about $40 \%$ of their time hunting between May and November. In 
December, hunting occurred $12.3 \%$ of the time, a decrease of $27.2 \%$ from November $(P<0.01)$. The frequency of hunting also fell (0.34, December; 0.89, November).

At carrion. Coyotes were observed at cow carrion about as frequently (Table 1) and for about the same proportion of time during fall and spring/summer $(P>0.05$, Fig. 1) and for a significantly greater proportion of time $(P<0.001$; Fig. 1) and more frequently (Table 1$)$ in winter when elk carrion was available. Also, the mean bout length of a visit to carrion was about twice as long during winter (Table 1). Between May and the end of November, coyotes were observed at carrion (cow) less than $2.2 \%$ of the time. The proportion of time spent at elk carrion increased about three-fold between December (9.1\%) and January (24.4\%; $P<0.05)$. In February, coyotes were observed at carrion $17.3 \%$ of the time and in March, when carrion became more scarce, only $7.5 \%$ of the time (comparing February to March, $P<0.05)$. In April when snow melted and small amounts of buried elk carrion became more accessible (and the pack defended its finds more vigorously) the proportion of time spent at carrion increased slightly to $10.5 \%$. In May, the percentage of time spent at carrion decreased to $0.12 \%$ (comparing April to May, $P<0.001$ ), and the frequency dropped from 0.45 (April) to 0.04 .

Playing. Coyotes played the same amount (Table 1 ) and for the same proportion of time throughout the year $(P>0.05$; Fig. 1$)$.

Aggression. Coyotes spent about the same amount of time engaged in aggressive encounters throughout the year $(P>0.05$; Fig. 1$)$, and there were no seasonal differences in frequency or mean bout length (Table 1). Aggressive interaction never accounted for more than $4 \%$ of time in any period.

Eating. Animals were observed to eat more frequently, but in shorter bouts, in fall and spring/summer, when they were dependent on small rodents, than in winter, when elk carrion was the main food source (Table 1).

\section{Behavioural Budgets and Social Organization}

We compared behavioural budgeting during winter by pack members, two adults comprising a resident pair, and solitary residents and transients (Fig. 2). During the course of the study, no identified individual changed social class. The pack consisted of a mated pair that were observed throughout the course of the study, a male presumably born to them in 1977 that helped to rear two subsequent litters born to the mated pair and then dispersed in February 1980, a male born in 1978 that died in February 1979, two females (one presumably born to the mated pair in 1977 and one born in 1978) that remained within the confines of their parents' and siblings' territory but rarely interacted with them, and a male and a female born in 1979. Copulatory ties were observed for the pack mated pair and the resident pair in 1979.

For all three groups, winter activities of rest and travel accounted for at least $86 \%$ of observed activity (Fig. 2). Proportionately, pack member rested significantly more $(P<0.001)$ and travelled significantly less $(P<0.001)$ than the resident pair or solitary residents or transients. The resident pair rested significantly more $(P<0.05)$ and also travelled significantly more $(P<0.001)$ than the solitary residents or transients. Pack members were observed at carrion for a significantly greater proportion of time than either the resident pair or solitary individuals $(P<0.001)$.

In the pack, there were only small differences among individuals in the percentage of time spent resting, travelling, and at carrion. For example the mother, father, and male helper born in 1977 were observed to rest $66 \%, 74 \%$, and $64 \%$ of the time, respectively. The percentages of time spent travelling for the same three individuals (in the same order) were 16\%,19\%, and 1.6\%, respectively. Likewise, each individual was observed at carrion about $21 \%$ of the time. 
Fig. 1. Percentage of time spent by coyotes in six activities between September 1977 and April 1980. Values have been standardized for the actual number of hours that coyotes were in view ('coyote-hours'; see Methods).

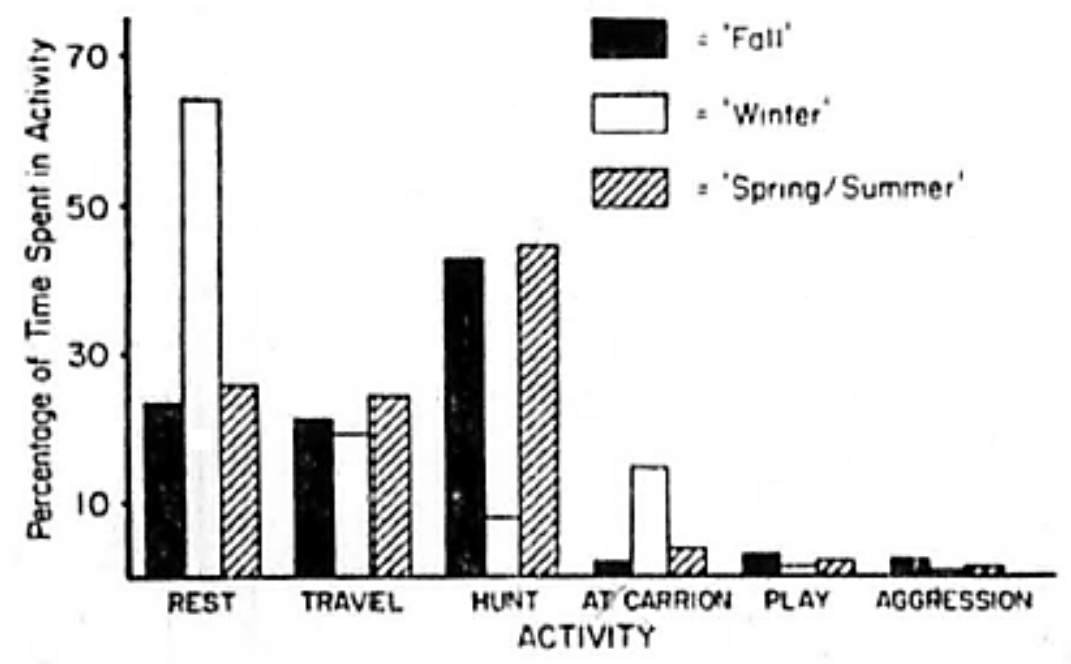

Fig. 2. Percentage of time spent in three activities during winter by coyotes of different social classes. Values have been standardized for the actual number of hours that coyotes were in view ('coyote-hours'; see Methods).

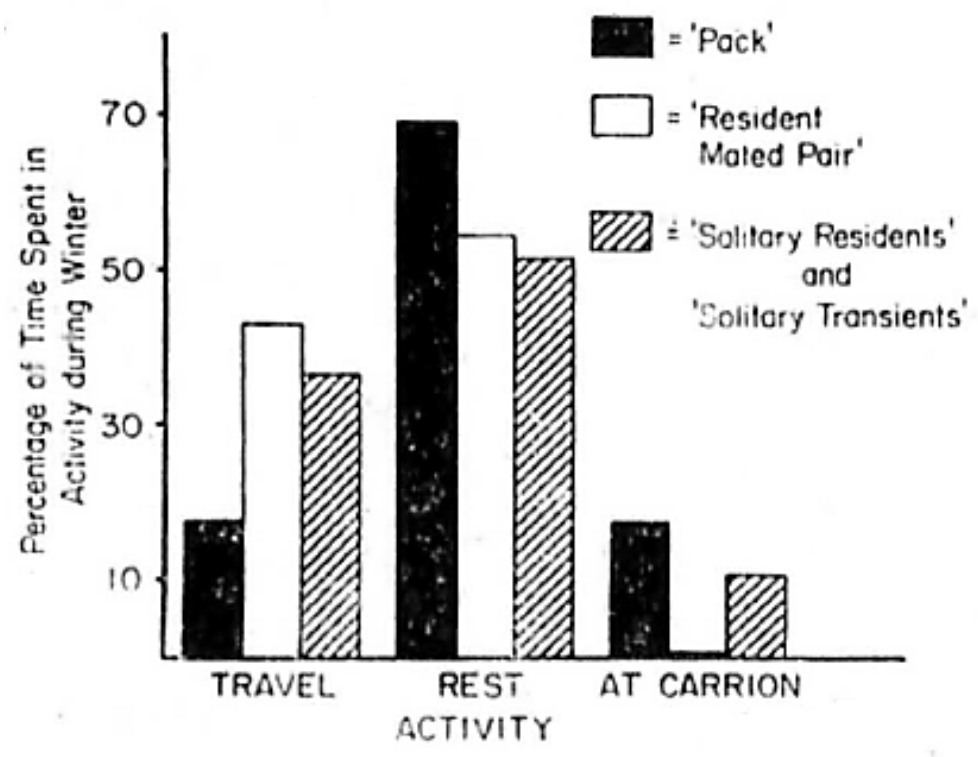

Comparison of the Pack Mated Pair with the Resident Mated Pair

The winter differences between the groups were clear (Fig. 3) and can be summarized as follows: (1) the pack female and male spent significantly more time resting $(P<0.001)$ and significantly less time travelling $(P<0.001)$ that the resident pair; $(2)$ the pack female rested significantly more than her mate $(P<0.001)$, but both individuals travelled about the same proportion of time $(P>0.05)$; $(3)$ in the resident pair, the female rested significantly more $(P<0.01)$ and travelled significantly less $(P<0.01)$ than her mate. 
Fig. 3. Percentage of time spent resting and travelling during winter by a mated pair living as part of a pack and by a mated resident pair living alone. Values have been standardized for the actual number of hours that coyotes were in view ('coyote-hours'; see Methods)

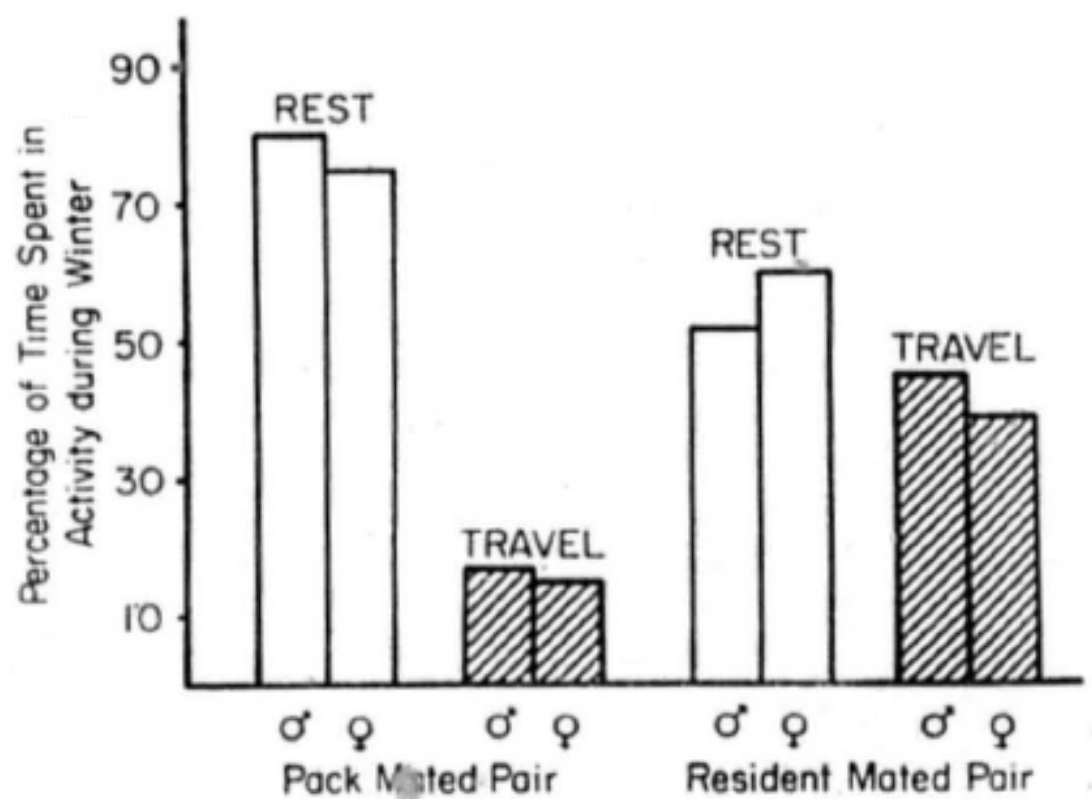

\section{Discussion}

Daytime activity patterns of coyote were influenced by proximate factors, specifically food resources and social organization, the latter of which is closely related to winter food availability (Bowen 1978; Camenzind 1978; Bekoff \& Wells 1980;). For example, when coyotes were primarily dependent on ungulate carrion (mainly elk) for winter food, the relative frequency and time pent resting increased while the frequency and time allotted to hunting decreased, when compared to the period of the year when small rodents constituted the major food supply.

Our results also support Bowen's (1978) suggestion that pack-living coyotes might show greater net energy gains when compared to individuals living other lifestyles. For example, the increase in resting during winter was primarily due to the behaviour of pack members, which rested more (and travelled less) than the resident pair or the solitary residents or transients, though all classes of coyotes rested more during winter than during other seasons. Packs of coyotes form when there is a clumped, groupdefendable winter food source consisting of large prey items (carcasses, piles of viscera), and pack formation by coyotes appears to be an adaptation for group defence of food rather than for the capture of large prey (Bowen 1978; Camenzind 1978; Bekoff \& Wells 1980). Pack member around Blacktail Butte only rarely left the confines of their territory, on which about $83 \%$ of all winter carrion in the area of the butte was located (Grand Teton National Park unpublished data). Indeed, the pack's territory measured $8.13 \mathrm{~km}^{2}$ while the mean home range size for resident pairs and solitary individuals was $21.9 \mathrm{~km}^{2}$ and $52.3 \mathrm{~km}^{2}$, respectively.

Although more time was spent resting during winter (therefore, there was less available time for other activities), the proportion of time spent travelling was the same throughout the year. However, the resident pair and solitary residents and transients spent more time travelling than did pack coyotes. Unlike pack members, these other coyotes had to travel widely In search of winter carrion. Wolves also 
rest more in winter, a phenomenon that may also be food-related. Mech (1977) found that when food was scarce, wolves, which are dependent on pack hunting to capture large ungulate prey, showed a decrease in winter daytime travel (food searching) and slept more than during period when food was abundant.

\section{Behavioural Budgets of Mated Pairs}

The mated female and male in the pack spent more time resting and less time travelling than did the resident pair female and male. Overall, the pack female spent $22 \%$ less time travelling than did the resident pair female. However, the relative difference between females is probably greater due to the fact that travelling in snow is much more difficult than travelling on solid ground (Golightly, personal communication; Ramaswamy et at. 1966; Fuller \& Keith 1980). Furthermore, the pack female bad more ready access to winter food, which of course was inextricably linked to her activity.

\section{Winter Activity and Reproduction}

In coyotes (and other species), nutritional factors affecting the health of reproductive females play an important role in various reproductive processes and in pup mortality (Gier 1968; Kennelly 1978 and references therein). The most significant impact of nutrition on coyote reproduction appears to be upon the number of females, especially yearlings, that breed and upon the number of ova shed (Weaver 1977). In winter month, maintenance costs probably increase, especially when the ambient temperature drop below a coyote's thermoneutral zone (about - $10 \mathrm{C}$; Shield 1972). This occurred frequently on our study area. Furthermore, the Basal Metabolic Rate (BMR) can increase as much as 1.25 times during pregnancy and 1.5 times during lactation when compared to the BMR of a non-pregnant female (Crampton \& Lloyd 1959). If food availability decreased greatly during winter, all individuals could experience a precarious balance between energy input (food) and expenditures. Indeed, Weaver (1977) found up to six-fold differences in coyote population indices among his study areas in Jackson Hole and concluded that these differences could be attributed to variations in the amount of ungulate carrion available during winter. Coyote populations were more dense where there had been more winter food.

On our study area, mid-March to mid-April could potentially be a stressful period for coyotes especially for pregnant females entering the second half of pregnancy. During this time, carrion is in very low supply and Uinta ground squirrels are not yet up. Nonetheless, during the course of our study we detected no differences between the pack and resident pair females with respect to general health and stamina (both had good winter pelage, showed a strong gait through the snow, and were very active soon after giving birth; when trapped, both females were healthy and both weighed $12.7 \mathrm{~kg}$ ). Litter sizes for 3 years for each female were only slightly different. The pack female produced seven pups in 1978, six in 1979, and 5 in 1980, while the resident pair female produced seven pups in 1978, four in 1979, and five in 1980. Pup survival during the first 5 months of life was equal. We were aware of no mortality during this period of time.

Although we detected no major differences in pup productivity or survival between the reproductive females, the differences in winter travel costs are real. If food became an important limiting factor, we would predict that pack females would be less affected than resident pair females (pack females also are more likely to receive help in rearing young; Bekoff \& Wells 1980; Camenzind 1978). In fact as mentioned above, our data indicated that all pack member would be better off energetically than coyotes living other lifestyles.

In conclusion, daytime behavioural budgets of coyotes were directly influenced by food availability and social organization. Although our study is limited to one coyote population, previous researchers have not been able to observe coyotes in as direct a manner. Data for other carnivores (and other coyote 
populations) that show intraspecific variability in social organization, such as golden jackals (C. aureus, Macdonald 1979), would provide useful comparative information. Data on nighttime activity are also needed (see Smith et al. 1981), but very difficult to gather by direct observation. The long-term effects of variations in behavioural budgeting among individuals living different lifestyles, especially reproductive females, awaits further study.

\section{Acknowledgments}

This study was supported in part by grants from NIMH (29571) and NSF (27616 and 23463), and by a Faculty Fellowship from the University of Colorado and a grant from the Harry Frank Guggenheim Foundation to M.B. We wish to thank the administrators of the Grand Teton National Park for their cooperation ring the course of our studies and for providing data on carrion availability. V. Lipetz, A. Rathbun C. Meaney, and J. Cook helped with observations. Karen Byers and Jan Logan drew the figures and Pat Holman typed the manuscript. Philip N. Lehner and Roger Powell provided comments on an earlier draft of this paper.

\section{REFERENCES}

Altmann, S. 1974. Baboons, space, time, and energy. Am. Zool., 14, 221-2411.

Andelt, W. F. \& Gipson, P. S. 1979. Home range, activity, and daily movements of coyotes. J. Wildl. Mgmt., 43, 944-951.

Bekoff, M. 1974. Social play and play-soliciting by infant canids. Am. Zool., 14, 323-341.

Bekoff, M. 1977. Canis latrans Say. Mammal. Species, 79, 1-9.

Bekoff, M. \& Byers, J. A. 1981. A critical reanalysis of the ontogeny and phylogeny of mammalian social and locomotor play: An ethological hornet's nest. In: Issues in Behavioral Development: The Bielefeld Interdisciplinary Conference (Ed. by K. Immelmann, G. Barlow, M. Main \& L. Petrinovieh). Cambridge and New York: Cambridge University Press. (In press.)

Bekoff, M. \& Well, M. 1980. The social ecology of coyotes. Scient. Am., 242, 130-148.

Bowen, W. D. 1978. Social organization of the coyote in relation to prey size. Ph.D. thesis, University of British Columbia, Vancouver.

Camenzind, F. J. 1978. Behavioral ecology of coyotes on the national Elk Refuge, Jackson, Wyoming. In: Coyotes: Biology, Behavior, and Management (Ed. M. Bekoff), pp. 267-294. New York: Acadamic Press.

Coelho, A. M., Bramblett, C. A. \& Quick, L. B. 1979. Activity patterns in howler and spider monkeys: An application of socio-bioenergetic method. In: Primate Ecology and Human Origins (Ed. by I. S. Bernstein \& E. O. Smith) pp. 175-199. New York: Garland.

Cole, G. F. 1969. The elk of Grand Teton and southern Yellowstone National Parks. Res. Rep. GRTE-N1. Moose, Wyoming: National Park Service.

Crampton, E. \& Lloyd, L. 1959. Fundamentals of Nutrition. San Francisco: W. H. Freeman.

Fuller, T. K. \& Keith, L. B. 1980. Wolf population dynamics and prey relationships in northeastern Alberta. J. Wildl. Mgmt., 44, 583-602.

Gier, H. T. 1968. Coyotes in Kansas. Kans. State Coll. Agric. Exp. Stat. Bull., 393, 1-118.

Gipson, P. S. \& Sealander, J. A. 1972. Home range and activity of the coyote (Canis latrans frustor) in Arkansas. Proc. Ann. Conf. Southeast Game and Fish Comm., 26, 82-95.

Hawbaker, S. 1974. Trapping North American Furbearers. Fort Loudon, Pa.: S. S. Hawbaker.

Kennelly, J. J. 1978. Coyote reproduction. In : Coyotes: Biology, Behavior, and Management (Ed. by M. Bekoff), pp. 73-93. New York: Academic Press.

Laundré, J. W. 1979. A behavioral study of home range utilization by coyotes on the INEL site in southeastern Idaho. Ph.D. thesis, Idaho State University, Pocatello. 
Lehner, P. N. 1978. Coyote communication. In: Coyotes: Biology, Behavior, and Management (Ed. by M. Bekoff), pp. 127-162. New York: Academic Press.

Litvaitis, J. A. \& Mautz, W. W. 1980. Food and energy use by captive coyote. J. Wildl. Mgmt., 44, 56-61.

Macdonald, D. W. 1979. The flexible social system of the golden jackal, Canis aureus. Behav. Ecol. Sociobiol., 5, 17-38.

McNab, B. K. 1980. Food habits, energetics, and the population biology of mammals. Am. Nat., 116, 106124.

Mech, L. D. 1977. Population trend and winter deer consumption in a Minnesota wolf pack. In: Proceedings of the 1975 Predator Symposium (Ed . by R. L. Phillips \& C. Jonkel ), pp. 55-83. Missoula, Mont.: University of Montana Press.

Moen, A. N. 1973. Wildlife Ecology. San Francisco: W. H. Freeman.

Mottus, L. W. 1969. General activity and maintenance behavior of coyotes in captivity. M.Sc. thesis, University of Alberta, Edmonton.

Murie, O. J. 1951. The Elk of North America. Washington, D.C.: Wildlife Management Institute.

Oswald, E. T. 1966. A synecological study of the forested moraines on the valley floor of Grand Teton National Park, Wyoming. Ph .D. thesis. Montana State University, Bozeman.

Ozoga, J. J. \& Harger, E. M. 1966. Winter activities and feeding habits of northern Michigan coyotes. J. Wildl. Mgmt., 30, 809-818.

Ramaswamy, S. S., Dua, G. L., Raizada, V. K., Dimri, G. P., Viswanathan, K. R., Madhaviah, J. \& Srisastava, T. N. 1966. Effects of looseness of now on energy expenditure in marching on snowcovered ground. J. appl. Physiol., 21, 1747-1749.

Shield, J. 1972. Acclimation and energy metabolism of the dingo, Canis dingo, and the coyote, Canis latrans. J. Zool. Lond., 168, 483-501.

Smith, G. J., Cary, J. R. \& Rongstad, O. J. 1981. Sampling strategies for radio-tracking coyotes. Wildl. Soc. Bull., In press).

Snedecor, G. W. 1956. Statistical methods, 5th edn. Ames, lowa : Iowa State College Press.

Sokal, R. R. \& Rohlf, F. J. 1969. Biometry. San Francisco: W. H. Freeman.

Turner. D. C. 1979. An analysis of time-budgeting by roe deer (Capreolus capreolus) in an agricultural area. Behaviour, 71, 246-290.

Vincent, L. \& Bekoff, M. 1978. Quantitative analyses of the ontogeny of predatory behavior in coyote, Canis latrans. Anim. Behav., 26, 225- 231.

Weaver. J. L. 1977. Coyote-food base relationships in Jackson Hole, Wyoming. M.Sc. thesis, Utah State University, Logan.

Wells. M. C. \& Lehner. P. N. 1978. The relative importance of the distance senses in coyote predatory behaviour. Anim. Behav., 26, 251-258. 